\title{
Vesicular Neurotransmitter Transporters in Huntington's Disease: Initial Observations and Comparison With Traditional Synaptic Markers
}

\author{
MASAHIKO SUZUKI, ${ }^{1,3,5}$ TIMOTHY J. DESMOND, ${ }^{3}$ ROGER L. ALBIN, ${ }^{2,4}$ AND KIRK A. FREY ${ }^{1,2,3 *}$ \\ ${ }^{1}$ Department of Radiology (Division of Nuclear Medicine), The University of Michigan, Ann Arbor, Michigan \\ ${ }^{2}$ Department of Neurology, The University of Michigan, Ann Arbor, Michigan \\ ${ }^{3}$ The Mental Health Research Institute, The University of Michigan, Ann Arbor, Michigan \\ ${ }^{4}$ The Geriatrics Research, Education and Clinical Center, Ann Arbor Veteran's Administration Medical Center, \\ Ann Arbor, Michigan \\ ${ }^{5}$ Department of Neurology, The Jikei University, School of Medicine, Tokyo, Japan
}

\begin{abstract}
KEY WORDS VAChT; VMAT2; choline acetyltransferase
\end{abstract}
\begin{abstract}
Markers of identified neuronal populations have previously suggested selective degeneration of projection neurons in Huntington's disease (HD) striatum. Interpretations are, however, limited by effects of compensatory regulation and atrophy. Studies of the vesicular monoamine transporter type-2 (VMAT2) and of the vesicular acetylcholine transporter (VAChT) in experimental animals indicate that they are robust markers of presynaptic integrity and are not subject to regulation. We measured dopamine and acetylcholine vesicular transporters to characterize the selectivity of degeneration in HD striatum. Brains were obtained at autopsy from four HD patients and five controls. Autoradiography was used to quantify radioligand binding to VMAT2, VAChT, the dopamine plasmalemmal transporter (DAT), benzodiazepine (BZ) binding sites, and D2-type dopamine receptors. The activity of choline acetyltransferase (ChAT) was determined as an additional marker of cholinergic neurons. Autoradiograms were analyzed by video-assisted densitometry and assessment of atrophy was made from regional structural areas in the coronal projection. Striatal VMAT2, DAT, and VAChT concentrations were unchanged or increased, while D2 and BZ binding and ChAT activity were decreased in HD. After atrophy correction, all striatal binding sites were decreased. However, the decrease in ChAT activity was 3-fold greater than that of VAChT binding. In addition to degeneration of striatal projection neurons, there are losses of extrinsic nigrostriatal projections and of striatal cholinergic interneurons in $\mathrm{HD}$ on the basis of vesicular transporter measures. There is also markedly reduced expression of ChAT by surviving cholinergic striatal interneurons. Synapse 41:329-336, 2001. ๑ 2001 Wiley-Liss, Inc.
\end{abstract}

\section{INTRODUCTION}

Huntington's disease (HD) is an autosomal dominant disorder characterized by slowly progressive motor, cognitive, and behavioral disturbances (Folstein, 1989). Each individual with an affected parent has a $50 \%$ chance of inheriting the HD gene and eventually manifesting the illness. Macroscopically, there is progressive brain atrophy with disproportionate striatal involvement in HD (Vonsattel et al., 1985). Neurochemical studies of the HD striatum suggest that intrinsic neurons are lost, while the terminals of extrinsic dopaminergic nigrostriatal projections are relatively preserved (McGeer et al., 1973; Perry et al., 1973; Bird and Iversen, 1974; Spokes, 1980; Ferrante et al., 1986). This observation led investigators to de- velopment of excitotoxic models of HD (Portera-Cailliau et al., 1995). However, there is conflicting evidence for the involvement vs. relative sparing of striatal cholinergic interneurons (McGeer et al., 1973; Bird and Iversen, 1974; Kanazawa et al., 1985; Ferrante et al., 1987a). Enzyme activity of choline acetyltransferase (ChAT) is markedly reduced in prior studies of HD

\footnotetext{
Contract grant sponsor: the National Institute of Aging; Contract grant number: USPHS AG08671; Contract grant sponsor: National Institute of Neurological Disorders and Stroke; Contract grant number: AG08671 and NS38166.

*Correspondence to: K.A. Frey, M.D., Ph.D., The University of Michigan Hospitals, Room B1G 412/0028 AGH 1500 East Medical Center Drive, Ann Arbor, MI 48109-0028. E-mail: kfrey@umich.edu

Received 14 February 2001; Accepted 9 April 2001
} 
(Spokes, 1980), while histological analyses suggest relative preservation of the large aspiny striatal neurons believed to be the cholinergic interneuronal phenotype (Kanazawa et al., 1985; Ferrante et al., 1987a).

In 1993, the HD Collaborative Research Group identified the gene and mutation responsible for HD (Huntington's Disease Collaborative Research Group, 1993). The HD gene defect is a trinucleotide repeat (CAG) expansion on chromosome 4p16.3 that encodes a protein now designated huntingtin. However, contrary to initial expectations, huntingtin is synthesized widely throughout the brain and body ( $\mathrm{Li}$ et al., 1993). The differential vulnerability of neuronal subpopulations in HD remains to be explained. Neurochemical markers identifying both preferentially affected and relatively spared neurons are thus of continued importance in HD research. Detailed investigations of marker enzymes and binding sites may lead not only to improved postmortem understanding of HD neurodegeneration (Bird, 1980; Ferrante et al., 1987a,b), but may also afford targets for in vivo imaging of $\mathrm{HD}$ and its progression (Holthoff et al., 1993; Turjanski et al., 1995; Weeks et al., 1996; Bohnen et al., 2000).

In the present study, we examined the relationships of vesicular transporter measures as markers of the integrity of presynaptic cholinergic synapses (the vesicular acetylcholine transporter; VAChT) and dopaminergic synapses (the vesicular monoaminergic transporter type-2; VMAT2) in HD striatum. These measures are compared to parallel assays of neurotransmitter receptors and enzymes reported previously in HD. In addition, we estimated the contribution of striatal atrophy to the measures of striatal marker concentrations, to better reflect the actual losses of neurons and synapses and to correlate with expected results of in vivo neurochemical imaging studies in HD.

\section{MATERIALS AND METHODS Effect of postmortem delay}

Possible effects of postmortem delay to tissue procurement and freezing were assessed in experimental animals under conditions mimicking human postmortem conditions. Adult male Sprague Dawley rats weighing approximately $200 \mathrm{~g}$ were killed by decapitation and the heads maintained at controlled temperature, mimicking the typical human postmortem cooling curve as described previously (Whitehouse et al., 1984). At $0,4,8$, and $24 \mathrm{~h}$ postmortem, groups of brains were dissected, frozen on dry ice, and covered with frozen section embedding medium to prevent desiccation. Brains were then stored in plastic bags at $-70^{\circ} \mathrm{C}$ until cryostat sectioning. Each brain was sectioned in the coronal plane using a cryostat microtome at approximately $-20^{\circ} \mathrm{C}$. Pairs of adjacent $20 \mu$-thick sections through the head of the caudate nucleus were thawmounted on poly-L-lysine-subbed microscope slides and air-dried. Slides were then stored at $-70^{\circ} \mathrm{C}$ until use in binding assays.

\section{Collection of human brain tissue}

All brain tissues used in this study were obtained from the Michigan Alzheimer's Disease Research Center (MADRC) Brain Bank. Brains were obtained from four patients (average age, $59 \pm 10$ years) with clinically diagnosed HD. Each HD subject (or their legal guardian) gave informed consent for brain donation prior to death. One HD patient (Patient 1, Table I) had been treated chronically with reserpine until the time of death (Table I) and was excluded from group assessments of VMAT2 and the dopamine plasmalemmal transporter (DAT) since prior studies have indicated significant lasting effects on these measures (Naudon et al., 1995; Koeppe et al., 1999). Five elderly subjects (average age, $67 \pm 15$ years) with no neurological or psychiatric disorders were obtained from The University of Michigan Hospitals autopsy service after informed consent of the next-of-kin and served as controls (Table I).

Brains were removed, hemispheres divided, and coronal slabs cut from one hemisphere and frozen for biochemical assays. Slabs were frozen rapidly over liquid nitrogen vapors, sealed in plastic to prevent desiccation, and stored at $-70^{\circ} \mathrm{C}$. The contralateral hemispheres were fixed and processed for routine neuropathological examination to verify the clinical diagnoses. The postmortem delay time was $18 \pm 6 \mathrm{~h}$ for the controls and $6 \pm 2 \mathrm{~h}$ for the HD patients.

\section{Human tissue preparation for autoradiography}

Blocks of brain tissue were identified and dissected corresponding to the head of the caudate nucleus, putamen, and nucleus accumbens (at the level of the decussation of the anterior commissure), the midglobus pallidus (including the posterior putamen), the cerebellar hemispheric cortex, and the superior gyrus of the frontal cortex. Each tissue block was sectioned coronally in a cryostat microtome at $-20^{\circ} \mathrm{C}$. Series of adjacent $20 \mu$-thick brain sections were thaw-mounted onto poly-L-lysine-coated microscope slides, dried, and stored at $-70^{\circ} \mathrm{C}$ until use in autoradiographic assays. Additional brain sections were collected in the frozen state and stored in test tubes at $-70^{\circ} \mathrm{C}$ for later enzymatic assays.

\section{Autoradiographic ligand binding assays}

Slide-mounted brain sections were incubated in one of a variety of radioligands under conditions that maximize and define specific binding for each assay (Table II). After incubation, slides were washed to remove nonspecific binding and dried. The radiolabeled sections were then apposed to tritium-sensitive film (Hyperfilm- ${ }^{3} \mathrm{H}$, Amersham, Arlington Heights, 
TABLE I. Subject characteristics

\begin{tabular}{|c|c|c|c|c|c|c|c|c|}
\hline $\begin{array}{l}\text { HD } \\
\text { subjects }\end{array}$ & $\begin{array}{l}\text { Gender } \\
(\mathrm{M} / \mathrm{F})\end{array}$ & $\begin{array}{c}\text { Age } \\
\text { (years) }\end{array}$ & $\begin{array}{l}\text { PMD } \\
\text { (hours) }\end{array}$ & $\begin{array}{c}\text { Disease } \\
\text { duration } \\
\text { (years) }\end{array}$ & $\begin{array}{l}\text { Cause of } \\
\text { death }\end{array}$ & Grade $^{1}$ & Medications $^{2}$ & Brain regions available \\
\hline 1 & $\mathrm{~F}$ & 72 & 7 & 10 & $\begin{array}{l}\text { Infarction of } \\
\text { pons }\end{array}$ & 3 & $\begin{array}{l}\text { diazepam, } 4 \mathrm{mg} \text { BID; chlorpromazine, } \\
100 \mathrm{mg} \text { TID; reserpine, } 0.25 \mathrm{mg} \text { QD }\end{array}$ & $\begin{array}{l}\text { FCtx, Caud, APut, PPut, } \\
\text { GP, Cbl }\end{array}$ \\
\hline 2 & M & 49 & 9 & 11 & Pneumonia & 4 & levodopa/carbidopa, 25/100 mg TID & $\begin{array}{l}\text { FCtx, Caud, APut, PPut, } \\
\text { GP, Cbl }\end{array}$ \\
\hline 3 & M & 56 & 4 & 9 & Dehydration & 3 & - & $\begin{array}{l}\text { FCtx, Caud, APut, PPut, } \\
\text { GP, Cbl }\end{array}$ \\
\hline 4 & $\mathrm{~F}$ & 61 & 6 & 10 & Septicemia & 4 & haloperidol, $6 \mathrm{mg}$ QID & $\begin{array}{l}\text { FCtx, Caud, APut, PPut, } \\
\text { GP, Cbl }\end{array}$ \\
\hline Mean & & 59 & $6^{*}$ & 10 & & & & \\
\hline $\mathrm{SD}$ & & 10 & 2 & 1 & & & & \\
\hline \multicolumn{9}{|l|}{$\begin{array}{l}\text { Control } \\
\text { subjects }\end{array}$} \\
\hline 1 & M & 43 & 9 & - & Septicemia & - & - & $\begin{array}{l}\text { FCtx, Caud, APut, PPut, } \\
\text { GP, Cbl }\end{array}$ \\
\hline 2 & M & 67 & 18 & - & MI & - & - & $\begin{array}{l}\text { FCtx, Caud, APut, PPut, } \\
\text { GP, Cbl }\end{array}$ \\
\hline 3 & M & 72 & 26 & - & Septicemia & - & - & $\begin{array}{l}\text { FCtx, Caud, APut, PPut, } \\
\text { GP, Cbl }\end{array}$ \\
\hline 4 & M & 70 & 16 & - & Pneumonia & - & - & FCtx, Caud, APut, Cbl \\
\hline 5 & $\mathrm{~F}$ & 85 & 21 & - & Pneumonia & - & - & FCtx, PPut, GP \\
\hline Mean & & 67 & 18 & & & & & \\
\hline SD & & 15 & 6 & & & & & \\
\hline
\end{tabular}

$* P=0.011$ vs. control.

APut = anterior putamen; Caud = caudate nucleus; Cbl = cerebellar cortex; FCtx = frontal cortex; GP = globus pallidus; HD = Huntington's disease; MI = myocardial infarction; PMD = postmortem delay to tissue freezing; PPut = posterior putamen.

${ }^{1}$ Grading of striatal atrophy in HD proposed by Vonsattel et al. (1985).

${ }^{2}$ Medications used regularly within 6 months of autopsy with CNS actions. Does not include medications received during resuscitation immediately prior to death.

TABLE II. Autoradiographic radioligand binding assay conditions

\begin{tabular}{|c|c|c|c|c|c|c|}
\hline $\begin{array}{l}\text { Target } \\
\text { measure }\end{array}$ & Ligand (nM) & $\begin{array}{c}\text { Specific } \\
\text { activity } \\
(\mathrm{Ci} / \mathrm{mmol})\end{array}$ & Displacer $(\mu \mathrm{M})$ & $\begin{array}{c}\text { Incubation } \\
\text { time/temp. } \\
\left(\min /{ }^{\circ} \mathrm{C}\right)\end{array}$ & $\begin{array}{l}\text { P.I. washing } \\
\# / \text { time/temp. } \\
\left(\# / \mathrm{min} /{ }^{\circ} \mathrm{C}\right)\end{array}$ & Reference \\
\hline VAChT & {$\left[{ }^{3} \mathrm{H}\right]$ vesamicol $(10)$} & 35 & MABV $(0.2)$ & $60 / 25$ & $2 / 1 / 4$ & Bianchi et al., 1997 \\
\hline D2 receptor & {$\left[{ }^{3} \mathrm{H}\right]$ raclopride $(2)$} & 78.4 & NMS (10) & $60 / 25$ & $3 / 5 / 4$ & Kohler and Radesater, 1986 \\
\hline $\mathrm{BZ}$ receptor & {$\left[{ }^{3} \mathrm{H}\right]$ flumazenil (5) } & 87 & clonazepam (5) & $30 / 25$ & $2 / 5 / 4$ & Burdette et al., 1995 \\
\hline VMAT2 & {$\left[{ }^{3} \mathrm{H}\right] \mathrm{MTBZ}(10)$} & 82 & TBZ (10) & $60 / 25$ & $2 / 2 / 4$ & Vander Borght et al., 1995b \\
\hline DAT & {$\left[{ }^{3} \mathrm{H}\right]$ WIN $35,428(3)$} & 84.5 & nomifensine (10) & $60 / 4$ & $2 / 1 / 4$ & Canfield et al., 1990 \\
\hline
\end{tabular}

$\mathrm{BZ}=$ benzodiazepine; D2 receptor = type-2 dopamine receptor; DAT = dopamine plasmalemmal transporter; MABV = methylaminobenzovesamicol; MTBZ = methoxytetrabenazine; NMS = N-methylspiroperidol; P.I. washing = postincubation washing; TBZ = tetrabenazine; VAChT = vesicular acetylcholine transporter; VMAT2 = vesicular monoamine transporter type-2; WIN 35,428 = 2- $\beta$-carbomethoxy-3 $\beta$-(4-fluorophenyl)tropane.

IL) in lightproof X-ray cassettes along with tritiumlabeled plastic standards (Pan et al., 1983). After appropriate exposure times, the films were developed with Kodak D-19 developer, fixed, and analyzed by densitometry.

Autoradiograms were analyzed by video-assisted densitometry (MCID M5 System; Imaging Research, St. Catherines, Ontario, Canada) using calibrated plastic standards to convert film density to apparent tissue radioactivity levels as described previously (Pan et al., 1983).

Regional cross-sectional areas $\left(\mathrm{mm}^{2}\right)$ were also determined from the digitized images of the basal ganglia structures for each subject. The nuclear areas were measured on images generated by the radioligands displaying the best contrast. Structural atrophy was assessed in each HD patient by expressing the individual brain regional area relative to the mean of the control group for that region.

\section{Choline acetyltransferase activity}

ChAT activity was measured by the formation of $\left[{ }^{14} \mathrm{C}\right]$ acetylcholine from $\left[1-{ }^{14} \mathrm{C}\right]$ acetyl-coenzyme-A and choline as described previously (Fonnum, 1975). Frozen tissue sections were homogenized in saline and aliquots assayed for enzyme activity and for protein concentration by the dye binding method of Smith et al. (1985) in which bicinchoninic acid is used to stabilize the reaction product.

\section{Statistical analysis}

All data are reported as group mean $\pm \mathrm{SD}$. In addition to assessments of neurochemical marker activities and levels per unit tissue, autoradiographic measures were analyzed after correction for structural atrophy. To reduce between-subject variability in ChAT enzyme activity measures, data were additionally evaluated after within-subject expression relative to the frontal cortex. In the present data as well as in prior reports 


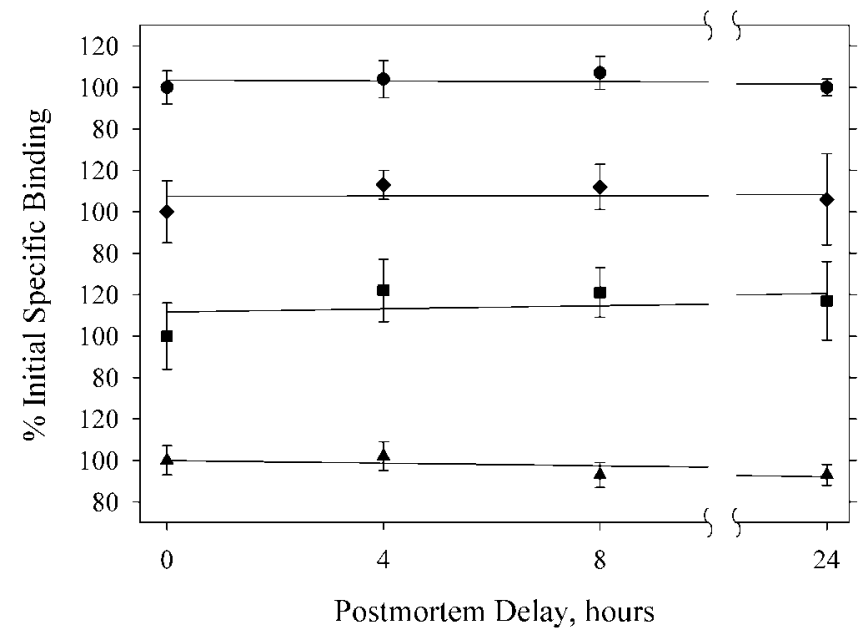

Fig. 1. Effect of simulated human postmortem delay to brain dissection and freezing on autoradiographic binding measures in rat striatum. Bindings of $\left[{ }^{3} \mathrm{H}\right]$ MTBZ to VMAT2 sites $(\bullet)$, of $\left[{ }^{3} \mathrm{H}\right]$ WIN 35,428 to DAT ( ), of $\left[{ }^{3} \mathrm{H}\right]$ vesamicol to VAChT (ם), and of $\left[{ }^{3} \mathrm{H}\right]$ flumazenil to benzodiazepine binding sites $(\mathbf{\Lambda})$ are depicted at various postmortem intervals relative to binding in immediately dissected and frozen tissues. Data represent the mean and SD of five subjects at each time point. There are no significant changes in the apparent binding densities of any of the markers studied with postmortem delays up to $24 \mathrm{~h}$.

(Bird and Iversen, 1974; Wong et al., 1982), neocortical ChAT activity is unaffected in HD. Differences between groups were assessed with Student's $t$-test, employing a significance threshold of $P<0.05$.

\section{RESULTS \\ Effect of postmortem delay on neurochemical marker autoradiography}

Binding assays for benzodiazepine (BZ) receptors, DAT, and the vesicular transporters VAChT and VMAT2 were not significantly affected by postmortem delays of at least $24 \mathrm{~h}$ in the rat brain under conditions mimicking human postmortem cooling (Fig. 1). Between $4-24 \mathrm{~h}$ of postmortem delay, there were less than 3\% losses of VMAT2, DAT, or VAChT bindings, while there was a nonsignificant mean loss of $9 \%$ of $\mathrm{BZ}$ receptors. Thus, the group differences in postmortem delay in the human assays are not likely to have contributed spurious findings, nor to have masked significant neurochemical losses in HD.

\section{Nigrostriatal dopaminergic markers}

VMAT2 concentration, as assessed by binding of $\left[{ }^{3} \mathrm{H}\right]$ methoxytetrabenazine (MTBZ), was increased significantly in the caudate nucleus ( $71 \%$ increase) and in the anterior $(72 \%)$ and posterior putamen $(25 \%)$ in HD (Fig. 2, Table III). Binding of MTBZ was reduced throughout the striatum in the subject excluded due to reserpine exposure (see Table III), attributable to the irreversible VMAT2 blockade. DAT concentration, as measured by $\left[{ }^{3} \mathrm{H}\right]$ WIN 35,428 binding, was increased by $33 \%$ in the caudate, $58 \%$ in the anterior putamen, and by $29 \%$ in the posterior putamen. DAT binding estimates were reduced by over $4 \mathrm{SD}$ in the excluded HD subject treated with reserpine relative to the remaining HD patients. After the introduction of atrophy correction, both DAT and VMAT2 demonstrated absolute mean striatal losses of 33-56\%, achieving statistical significance for DAT reduction in the posterior putamen (39\% reduction).

\section{Intrinsic striatal markers}

Autoradiographic measures of $\mathrm{BZ}$ receptor concentrations were significantly reduced throughout the HD striatum by $48-75 \%$ (Fig. 2, Table III). The reduction in posterior putamen was almost twice as great as that observed in the anterior striatal regions. In the globus pallidus, BZ receptor concentration was increased over control by almost $200 \%$. Dopamine D2 receptor concentration was also reduced throughout the striatum, achieving statistical significance in the anterior $(24 \%$ reduction) and posterior putamen (33\% reduction). Unlike the $\mathrm{BZ}$ receptors, the reduction of $\mathrm{D} 2$ binding was relatively uniform across the striatal subregions. After introduction of atrophy correction, both absolute BZ and D2 receptor numbers were further reduced in all striatal regions. The increased $\mathrm{BZ}$ receptor binding concentration in the globus pallidus was indicative of only $33 \%$ absolute increase in binding sites after correction for structural atrophy.

\section{Extrastriatal benzodiazepine receptor binding}

Flumazenil (FMZ) binding to BZ receptors in the HD frontal cortex was normal (Table III). Conversely, binding in the HD cerebellar cortex was increased significantly by $28 \%$.

\section{Presynaptic cholinergic indices}

Binding assays of VAChT concentration revealed nonsignificant increases per unit tissue throughout the striatum and were normal in the HD frontal cortex and cerebellum (Fig. 2, Table III). After introduction of atrophy correction, absolute VAChT binding was reduced throughout the striatum, achieving significance in the anterior (53\% reduction) and posterior (33\% reduction) putamen. Measures of ChAT activity per unit tissue were essentially normal in HD frontal cortex and cerebellum (Table IV), while there were nonsignificant trends toward reductions in the caudate nucleus and putamen. After expression of enzyme activity relative to frontal cortex, statistically significant ChAT reductions were identified in the caudate nucleus (71\% reduction) and in the posterior putamen (81\% reduction). The opposing directions of ChAT and VAChT changes in the HD striatum resulted in a significant, nearly 4 -fold, reduction in the relative ChATto-VAChT ratio in the caudate nucleus. After expression relative to the frontal cortex marker activities, the 


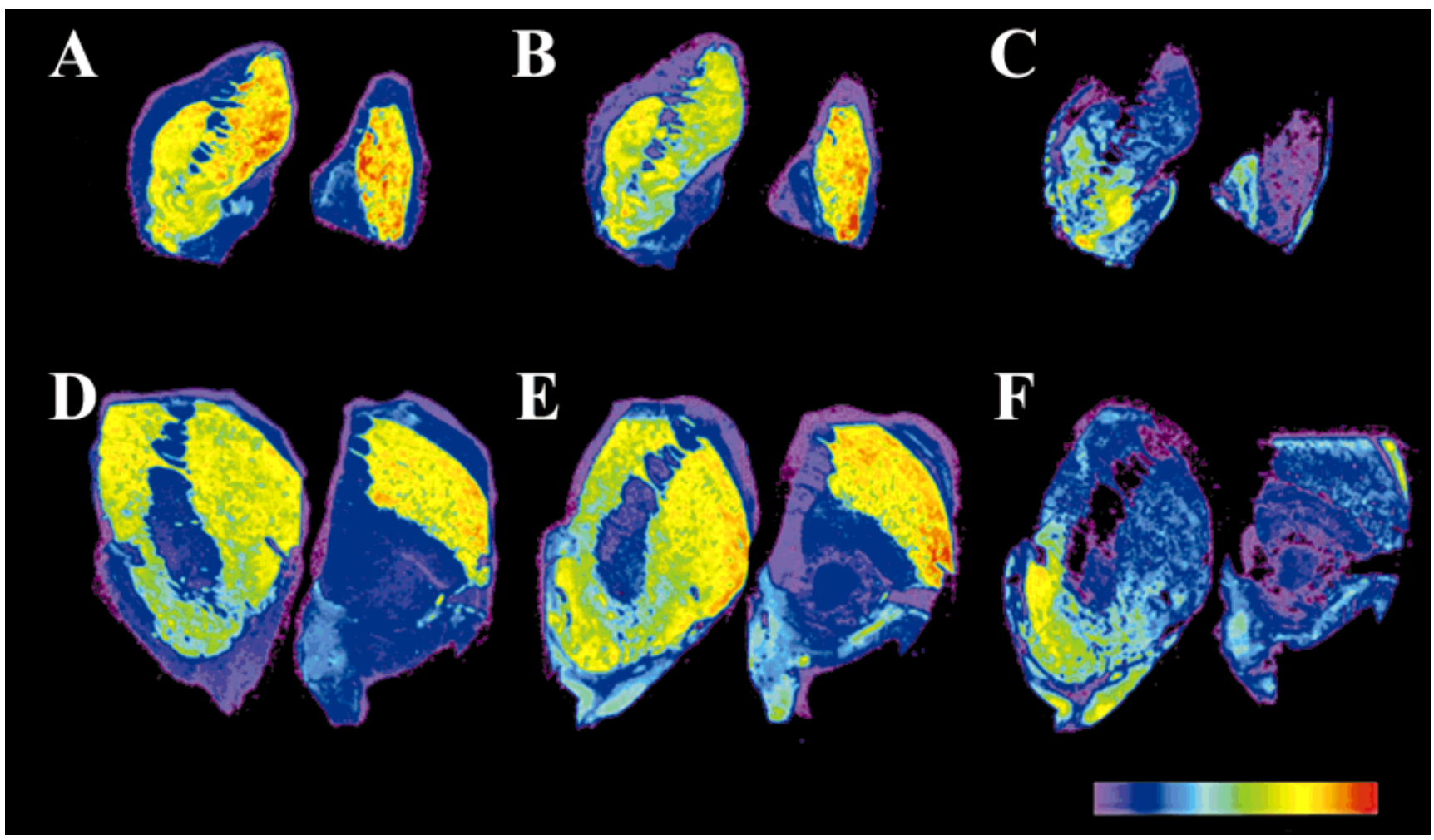

Fig. 2. Vesicular neurotransmitter transporter autoradiography. Representative autoradiograms of striatal nuclei from HD are depicted in the top row (A-C) and comparison normal samples are in the bottom row (D-F). In each image pair, the leftmost section includes the caudate nucleus and anterior putamen and the rightmost section includes the posterior putamen and globus pallidus. VMAT2 (A,D), $\mathrm{VAChT}(\mathbf{B}, \mathbf{E})$, and benzodiazepine binding site $(\mathbf{C}, \mathbf{F})$ concentrations

ChAT-to-VAChT ratios were found significantly reduced in the caudate nucleus ( $80 \%$ reduction) and in the posterior putamen ( $83 \%$ reduction).

\section{DISCUSSION \\ Selectivity of neuronal degeneration in HD}

Our results confirm marked losses of intrinsic striatal synaptic markers in HD including BZ (Walker et al., 1984; Kanazawa et al., 1985; Whitehouse et al., 1985; Ellison et al., 1987; Reynolds et al., 1990) and dopamine D2 (Whitehouse et al., 1985; Brandt et al., 1990; Richfield et al., 1991; Ichise et al., 1993; Weeks et al., 1996) receptors. Contrary to initial reports, however, we find evidence that degeneration is not confined to the striatal projection neurons alone and does not affect all striatal neurons equally. We find evidence for losses in nigrostriatal projection terminals, as reflected in reduced absolute numbers of VMAT2 binding sites. In addition, we have novel evidence for dissociation of the two presynaptic cholinergic neurochemical markers, ChAT and VAChT, reconciling discrepant prior data (Kish et al., 1990; Ruberg et al., 1990; Murman et al., 1994) on cholinergic interneurons in HD. Together, these results confirm that there are selective effects on GABAergic striatal projection neurons in HD, but that are displayed in pseudocolor according to the scale at the bottom right (red = highest binding; violet $=$ lowest binding). Note increased concentrations of VMAT2 and VAChT and marked atrophy in caudate and putamen. After adjustment for atrophy, both vesicular transporters are reduced in HD relative to control (see text, Table III). Benzodiazepine binding is reduced in striatum and increased in globus pallidus.

the pathology is only relatively, rather than absolutely, selective.

Original neurochemical analyses of HD striatum revealed normal or elevated levels of dopamine and related synthetic enzymes, suggesting preservation of the nigrostriatal projection (Bernheimer et al., 1973; McGeer and McGeer, 1976; Spokes, 1980; Albin et al., 1990). Experimental animal models of HD employing glutamatergic excitotoxins reveal similar preservation or elevation of nigrostriatal markers per unit tissue of lesioned striatum (Gehlert and Schoepp, 1992). Other studies, however, have suggested that substantia nigra pars compacta neurons are lost in HD (Oyanagi et al., 1989; Gibb, 1991). Some investigators have also reported losses of dopamine and of its metabolite homovanillic acid (Kish et al., 1987). In the present studies, we have confirmed prior observations that striatal presynaptic dopaminergic markers are increased per unit tissue in HD. Before atrophy correction, the binding site concentrations of DAT and of VMAT2 in the putamen were significantly increased. However, after atrophy correction the absolute numbers of these markers were decreased throughout the striatum, achieving statistical significance in the posterior putamen for VMAT2 reduction. While interpretation of re- 
TABLE III. Striatal synaptic markers before and after correction for atrophy

\begin{tabular}{|c|c|c|c|c|c|c|c|}
\hline \multirow[b]{2}{*}{$\begin{array}{l}\text { Neurochemical } \\
\text { marker }\end{array}$} & \multirow[b]{2}{*}{ Group } & \multicolumn{6}{|c|}{ Specific ligand binding (dpm/ $\mathrm{g}$ protein) } \\
\hline & & $\begin{array}{l}\text { Caudate } \\
\text { nucleus }\end{array}$ & $\begin{array}{l}\text { Anterior } \\
\text { putamen }\end{array}$ & $\begin{array}{l}\text { Posterior } \\
\text { putamen }\end{array}$ & $\begin{array}{l}\text { Globus } \\
\text { pallidus }\end{array}$ & Cerebellum & $\begin{array}{l}\text { Frontal } \\
\text { cortex }\end{array}$ \\
\hline \multirow{4}{*}{ VAChT } & Control $(n=4)$ & $40 \pm 4$ & $59 \pm 9$ & $72 \pm 8$ & $5 \pm 1$ & $8 \pm 2$ & $8 \pm 1^{2}$ \\
\hline & $\mathrm{HD}(n=4)$ & $55 \pm 12$ & $69 \pm 24$ & $105 \pm 34$ & $14 \pm 4^{*}$ & $6 \pm 2$ & $7 \pm 1$ \\
\hline & HD corrected $^{1}(n=4)$ & $19 \pm 14$ & $28 \pm 9 * *$ & $48 \pm 7 * *$ & $7 \pm 3$ & - & - \\
\hline & Control $(n=4)$ & $64 \pm 4$ & $77 \pm 10$ & $62 \pm 13$ & $31 \pm 3$ & $130 \pm 5$ & $267 \pm 32^{2}$ \\
\hline \multirow[t]{3}{*}{$\mathrm{BZ}$ receptor } & $\mathrm{HD}(n=4)$ & $33 \pm 20 *$ & $40 \pm 6^{* *}$ & $16 \pm 5 * *$ & $93 \pm 31$ & $166 \pm 22^{*}$ & $292 \pm 10$ \\
\hline & HD corrected $^{1}(n=4)$ & $12 \pm 9 * *$ & $19 \pm 11^{* *}$ & $8 \pm 2 * *$ & $45 \pm 22$ & - & - \\
\hline & Control $(n=4)$ & $13 \pm 1$ & $13 \pm 1$ & $15 \pm 3$ & $3 \pm 2$ & - & - \\
\hline \multirow{3}{*}{$\mathrm{D} 2$ receptor } & $\mathrm{HD}(n=4)$ & $10 \pm 3$ & $10 \pm 1 *$ & $10 \pm 3^{*}$ & $3 \pm 1$ & - & - \\
\hline & HD corrected $^{1}(n=4)$ & $4 \pm 2^{* *}$ & $5 \pm 3 * *$ & $5 \pm 2 * *$ & $1 \pm 1$ & - & - \\
\hline & Control $(n=4)$ & $109 \pm 25$ & $109 \pm 14$ & $155 \pm 21$ & $9 \pm 1$ & - & - \\
\hline \multirow[t]{3}{*}{ VMAT2 } & $\operatorname{HD}^{3}(n=3)$ & $186 \pm 65$ & $187 \pm 35^{*}$ & $193 \pm 81$ & $18 \pm 6$ & - & - \\
\hline & HD corrected $^{1}(n=3)$ & $58 \pm 37$ & $70 \pm 31$ & $94 \pm 11^{* *}$ & $9 \pm 4$ & - & - \\
\hline & Control $(n=4)$ & $45 \pm 12$ & $43 \pm 11$ & $49 \pm 5$ & $3 \pm 1$ & - & - \\
\hline \multirow[t]{2}{*}{ DAT } & $\mathrm{HD}^{4}(n=3)$ & $60 \pm 8$ & $68 \pm 6^{*}$ & $63 \pm 15$ & $5 \pm 2$ & - & - \\
\hline & HD corrected $^{1}(n=3)$ & $20 \pm 13$ & $27 \pm 16$ & $33 \pm 14$ & $3 \pm 1$ & - & - \\
\hline
\end{tabular}

$* P<0.05$ vs. control.

$\mathrm{BZ}=$ benzodiazepine; D2 receptor = type-2 dopamine receptor; DAT = dopamine plasmalemmal transporter; HD = Huntington's disease; VAChT = vesicular acetylcholine transporter; VMAT2 = vesicular monoamine transporter type-2.

${ }^{1}$ Atrophy assessment revealed significant $(P<0.02$ or lower $)$ area losses of $66 \pm 15 \%$ in the caudate nucleus, of $54 \pm 23 \%$ in the anterior putamen, of $45 \pm 14 \%$ in the posterior putamen and of $55 \pm 9 \%$ in the globus pallidus of $\mathrm{HD}$ relative to controls.

${ }^{2} N=5$ subjects studied in this region.

${ }^{3}$ Values obtained in the excluded HD subject receiving reserpine treatment (Subject \#1, Table I): caudate-130; anterior putamen-168; posterior putamen-185; globus pallidus-19.

${ }^{4}$ Values obtained in the excluded HD subject receiving reserpine treatment (Subject \#1, Table I): caudate-20; anterior putamen-23; posterior putamen-24; globus pallidus-5.

TABLE IV. Presynaptic cholinergic markers in HD

\begin{tabular}{|c|c|c|c|c|c|c|}
\hline Parametric measures & Group & $\begin{array}{l}\text { Caudate } \\
\text { nucleus }\end{array}$ & $\begin{array}{l}\text { Anterior } \\
\text { putamen }\end{array}$ & $\begin{array}{l}\text { Posterior } \\
\text { putamen }\end{array}$ & Cerebellum & $\begin{array}{l}\text { Frontal } \\
\text { cortex }\end{array}$ \\
\hline \multirow[t]{2}{*}{ ChAT } & Control $(n=4)$ & $75 \pm 25$ & $109 \pm 69$ & $104 \pm 56$ & $4 \pm 3$ & $4 \pm 1^{1}$ \\
\hline & $\mathrm{HD}(n=4)$ & $31 \pm 40$ & $54 \pm 89$ & $33 \pm 57$ & $3 \pm 5$ & $4 \pm 2$ \\
\hline \multirow[t]{2}{*}{ VAChT } & Control $(n=4)$ & $40 \pm 4$ & $59 \pm 9$ & $72 \pm 8$ & $8 \pm 2$ & $8 \pm 1^{1}$ \\
\hline & $\mathrm{HD}(n=4)$ & $55 \pm 12$ & $69 \pm 24$ & $105 \pm 34$ & $6 \pm 2$ & $7 \pm 1$ \\
\hline \multirow[t]{2}{*}{ ChAT/VAChT } & Control $(n=4)$ & $1.9 \pm 0.5$ & $1.8 \pm 1.0$ & $1.4 \pm 0.7$ & $0.5 \pm 0.2$ & $0.5 \pm 0.1^{1}$ \\
\hline & $\mathrm{HD}(n=4)$ & $0.5 \pm 0.6^{*}$ & $0.9 \pm 1.6$ & $0.4 \pm 0.8$ & $0.4 \pm 0.6$ & $0.5 \pm 0.3$ \\
\hline \multirow{2}{*}{ ChAT } & Control $(n=4)$ & $21 \pm 5$ & $30 \pm 16$ & $27 \pm 12$ & $1 \pm 1$ & \\
\hline & $\mathrm{HD}(n=4)$ & $6 \pm 5^{* *}$ & $9 \pm 12$ & $5 \pm 8^{*}$ & $1 \pm 1$ & \\
\hline \multirow[t]{2}{*}{ VAChT } & Control $(n=4)$ & $4.7 \pm 0.8$ & $6.9 \pm 1.3$ & $9.1 \pm 2.5$ & $1.0 \pm 0.3$ & \\
\hline & $\mathrm{HD}(n=4)$ & $7.7 \pm 2.3$ & $9.5 \pm 3.8$ & $15.1 \pm 7.2$ & $0.8 \pm 0.2$ & \\
\hline \multirow[t]{2}{*}{ ChAT/VAChT } & Control $(n=4)$ & $4.4 \pm 0.5$ & $4.3 \pm 1.8$ & $2.9 \pm 0.7$ & $1.0 \pm 0.3$ & \\
\hline & $\mathrm{HD}(n=4)$ & $0.9 \pm 0.7^{* *}$ & $1.2 \pm 1.7$ & $0.5 \pm 0.8^{* *}$ & $0.7 \pm 0.5$ & \\
\hline
\end{tabular}

$* P<0.05$ vs. control.

$* * P<0.01$ vs. control.

ChAT $=$ choline acetyltransferase enzyme activity $(\mathrm{nmol} / \mathrm{h} / \mathrm{mg}$ protein); HD = Huntington's disease; VAChT = vesicular acetylcholine transporter radioligand

binding $(\mathrm{dpm} / \mu \mathrm{g}$ protein).
${ }^{1} N=5$ subjects studied in this region.

duced DAT binding includes either a reduced density of dopaminergic nerve terminals or reduced DAT expression per terminal, prior work in experimental animals indicates that the latter is not likely for VMAT2 (Vander Borght et al., 1995a). Our findings of reduced VMAT2 in the striatum therefore strongly favor losses of nigrostriatal terminals in HD. In vivo DAT imaging is in agreement with our atrophy-corrected projections, indicating a 50\% loss of binding in HD striatum (Ginovart et al., 1997). Recent in vivo studies with the VMAT2 ligand $\left[{ }^{11} \mathrm{C}\right]$ dihydrotetrabenazine also indicate loss of dopamine terminals, particularly in the posterior putamen (Bohnen et al., 2000).

Histological studies indicate relative preservation of large aspiny interneurons in HD striatum that are associated with the cholinergic phenotype in normal subjects (Lange et al., 1976; Parent et al., 1984; Kanazawa et al., 1985; Ferrante et al., 1987a). However, neurochemical assays reveal significant reductions of the marker enzyme ChAT, suggesting degeneration of the striatal cholinergic neurons (Bird and Iversen, 1974; McGeer and McGeer, 1976; Spokes, 1980; Kanazawa et al., 1985; Hirsch et al., 1989).

Our present measurements of cholinergic markers confirm the findings of the prior ChAT activity studies and, importantly, provide explanation for the apparent discrepancy between enzymology and histopathology of the striatal cholinergic interneurons. Our measures of VAChT binding indicate that there is a significant dissociation of vesicle transporter levels from ChAT activity. We observed a 3-4-fold difference in the relative measures of striatal ChAT and VAChT in HD relative 
to control striatum, suggesting decreased enzyme activity in neurons that continue to express vesicular transporters for acetylcholine. Studies from our laboratory on VAChT radioligand binding indicate that it is specific for cholinergic presynaptic terminals and that the expressed level of VAChT binding is not regulated during chronic cholinesterase inhibition or muscarinic cholinergic receptor blockade (Bianchi et al., 1997). Thus, the present findings suggest relative preservation of cholinergic interneurons in HD striatum, in keeping with histological observations, but with diminished ChAT activity. However, our data further indicate that there are losses of cholinergic interneurons in HD. After introduction of atrophy correction, the relatively increased striatal concentration of VAChT binding per unit tissue corresponds to a reduction by at least $50 \%$ in total striatal VAChT binding. Thus, our data confirm the relative structural sparing of cholinergic interneurons in $\mathrm{HD}$, but indicate that actual losses are comparable to those in extrinsic nigrostriatal projections, as discussed previously.

\section{Postmortem delay}

There is a significant difference of postmortem duration between the HD and comparison groups in our study. This difference would be expected to bias in favor of smaller distinctions between the groups if the predominant effect of postmortem delay is proteolysis and loss of tissue integrity. We directly assessed the possible effect of postmortem delay on the measured binding assays in an experimental animal model. We found no significant alterations of BZ receptor antagonist binding and no significant alterations in bindings of ligands to the DAT or to the vesicular transporters VMAT2 and VAChT. We therefore interpret the results of the human postmortem tissue assays as representative of disease- and treatment-related changes, rather than of postmortem effect.

\section{Striatal atrophy adjustment}

We introduced adjustments of our binding measures for the effects of atrophy in the basal ganglia nuclei as assessed autoradiographically. It is important to note that these corrections are at best approximate, since they reflect only changes in cross-sectional area in the coronal plane. In order to more accurately adjust for atrophy, regular sampling throughout the rostro-caudal extent of each nucleus would be necessary. However, this sampling frequency is beyond the scope of our present experiments. The estimates of atrophy made in two dimensions in our present calculations are very likely to underestimate its actual impact. If, for example, atrophy were equivalent in the rostro-caudal dimension to that in the coronal sections, actual striatal volume reductions would be approximately $15 \%$ greater (assuming 30\% radial shrinkage and spherical geometry of the measured nuclei). Despite likely undercorrection for tissue atrophy, our results demonstrate significant losses of all neuronal markers in HD striatum, including projection neurons, cholinergic interneurons, and nigrostriatal terminals.

\section{REFERENCES}

Albin RL, Reiner A, Anderson KD, Penney JB, Young AB. 1990. Striatal and nigral neuron subpopulations in rigid Huntington's disease: implications for the functional anatomy of chorea and rigidity-akinesia. Ann Neurol 27:357-365.

Bernheimer H, Birkmayer W, Hornykiewicz O, Jellinger K, Seitelberger F. 1973. Brain dopamine and the syndromes of Parkinson and Huntington. Clinical, morphological and neurochemical correlations. J Neurol Sci 20:415-455.

Bianchi MT, Desmond TJ, Frey KA. 1997. Expression of the vesicular acetylcholine transporter is unaltered by pharmacological interventions in cholinergic transmission. Soc Neurosci Abstr 23:695.

Bird ED. 1980. Chemical pathology of Huntington's disease. Annu Rev Pharmacol Toxicol 20:533-551.

Bird ED, Iversen LL. 1974. Huntington's chorea. Post-mortem measurement of glutamic acid decarboxylase, choline acetyltransferase and dopamine in basal ganglia. Brain 97:457-472.

Bohnen NI, Koeppe RA, Meyer P, Ficaro E, Wernette K, Kilbourn MR, Kuhl DE, Frey KA, Albin RL. 2000. Decreased striatal monoaminergic terminals in Huntington disease. Neurology 54:1753-1759.

Brandt J, Folstein SE, Wong DF, Links J, Dannals RF, McDonnellSill A, Starkstein S, Anders P, Strauss ME, Tune LE. 1990. D2 receptors in Huntington's disease: positron emission tomography findings and clinical correlates. J Neuropsychiatry Clin Neurosci $2: 20-27$.

Burdette DE, Sakurai SY, Henry TR, Ross DA, Pennell PB, Frey KA, Sackellares JC, Albin RL. 1995. Temporal lobe central benzodiazepine binding in unilateral mesial temporal lobe epilepsy. Neurology 45:934-941.

Canfield DR, Spealman RD, Kaufman MJ, Madras BK. 1990. Autoradiographic localization of cocaine binding sites by $[3 \mathrm{H}] \mathrm{CFT}$ ([3H]WIN 35,428) in the monkey brain. Synapse 6:189-195

Ellison DW, Beal MF, Mazurek MF, Malloy JR, Bird ED, Martin JB. 1987. Amino acid neurotransmitter abnormalities in Huntington's disease and the quinolinic acid animal model of Huntington's disease. Brain 110:1657-1673.

Ferrante RJ, Kowall NW, Richardson EP Jr, Bird ED, Martin JB. 1986. Topography of enkephalin, substance $P$ and acetylcholinesterase staining in Huntington's disease striatum. Neurosci Lett 71: $283-288$.

Ferrante RJ, Beal MF, Kowall NW, Richardson EP Jr, Martin JB. 1987a. Sparing of acetylcholinesterase-containing striatal neurons in Huntington's disease. Brain Res 411:162-166.

Ferrante RJ, Kowall NW, Beal MF, Martin JB, Bird ED, Richardson EP Jr. 1987b. Morphologic and histochemical characteristics of a spared subset of striatal neurons in Huntington's disease. J Neuropathol Exp Neurol 46:12-27.

Folstein SE. 1989. Huntington's disease: a disorder of families. Baltimore: Johns Hopkins University Press.

Fonnum F. 1975. A rapid radiochemical method for the determination of choline acetyltransferase. J Neurochem 24:407-409.

Gehlert DR, Schoepp DD. 1992. Striatal quinolinic acid lesions increase [3H]WIN 35,428 binding to the dopamine transporter. Neurochem Int 21:581-584.

Gibb WR. 1991. Neuropathology of the substantia nigra. Eur Neurol $31: 48-59$.

Ginovart N, Lundin A, Farde L, Halldin C, Backman L, Swahn CG, Pauli S, Sedvall G. 1997. PET study of the pre- and post-synaptic dopaminergic markers for the neurodegenerative process in Huntington's disease. Brain 120:503-514.

Hirsch EC, Graybiel AM, Hersh LB, Duyckaerts C, Agid Y. 1989 Striosomes and extrastriosomal matrix contain different amounts of immunoreactive choline acetyltransferase in the human striatum. Neurosci Lett 96:145-150.

Holthoff VA, Koeppe RA, Frey KA, Penney JB, Markel DS, Kuhl DE, Young AB. 1993. Positron emission tomography measures of benzodiazepine receptors in Huntington's disease. Ann Neurol 34:7681.

Huntington's Disease Collaborative Research Group. 1993. A novel gene containing a trinucleotide repeat that is expanded and unstable on Huntington's disease chromosomes. Cell 72:971-983.

Ichise M, Toyama H, Fornazzari L, Ballinger JR, Kirsh JC. 1993. Iodine-123-IBZM dopamine D2 receptor and technetium-99m-HM- 
PAO brain perfusion SPECT in the evaluation of patients with and subjects at risk for Huntington's disease. J Nucl Med 34:12741281.

Kanazawa I, Sasaki H, Muramoto O, Matsushita M, Mizutani T, Iwabuchi K, Ikeda T, Takahata N. 1985. Studies on neurotransmitter markers and striatal neuronal cell density in Huntington's disease and dentatorubropallidoluysian atrophy. J Neurol Sci 70: 151-165.

Kish SJ, Shannak K, Hornykiewicz O. 1987. Elevated serotonin and reduced dopamine in subregionally divided Huntington's disease striatum. Ann Neurol 22:386-389.

Kish SJ, Distefano LM, Dozic S, Robitaille Y, Rajput A, Deck JH, Hornykiewicz O. 1990. [3H]Vesamicol binding in human brain cholinergic deficiency disorders. Neurosci Lett 117:347-352.

Koeppe RA, Kilbourn MR, Taylor SF, Meador-Woodruff JM, Frey KA, Kuhl DE. 1999. Evaluation of specific binding of [11C]dihydrotetrabenazine using active $(+)$ and inactive $(-)$ enantiomers. J Cereb Blood Flow Metab 19(Suppl 1):S798.

Kohler C, Radesater AC. 1986. Autoradiographic visualization of dopamine D-2 receptors in the monkey brain using the selective benzamide drug $[3 \mathrm{H}]$ raclopride. Neurosci Lett 66:85-90.

Lange H, Thorner G, Hopf A, Schroder KF. 1976. Morphometric studies of the neuropathological changes in choreatic diseases. J Neurol Sci 28:401-425.

Li SH, Schilling G, Young WS 3rd, Li XJ, Margolis RL, Stine OC, Wagster MV, Abbott MH, Franz ML, Ranen NG. 1993. Huntington's disease gene (IT15) is widely expressed in human and rat tissues. Neuron 11:985-993.

McGeer PL, McGeer EG. 1976. Enzymes associated with the metabolism of catecholamines, acetylcholine and gaba in human controls and patients with Parkinson's disease and Huntington's chorea. J Neurochem 26:65-76.

McGeer PL, McGeer EG, Fibiger HC. 1973. Choline acetylase and glutamic acid decarboxylase in Huntington's chorea. A preliminary study. Neurology 23:912-917.

Murman DL, Desmond TJ, Higgins DS, Hermanowicz NS, Penney JBJ, Frey KA. 1994. Autoradiographic quantification of the vesamicol receptor in Alzheimer's disease. Neurology 44(Suppl 2):A389.

Naudon L, Leroux-Nicollet I, Raisman-Vozari R, Botton D, Costentin J. 1995. Time-course of modifications elicited by reserpine on the density and mRNA synthesis of the vesicular monoamine transporter, and on the density of the membrane dopamine uptake complex. Synapse 21:29-36.

Oyanagi K, Takeda S, Takahashi H, Ohama E, Ikuta F. 1989. A quantitative investigation of the substantia nigra in Huntington's disease. Ann Neurol 26:13-19.

Pan HS, Frey KA, Young AB, Penney JB Jr. 1983. Changes in $[3 \mathrm{H}]$ muscimol binding in substantia nigra, entopeduncular nucleus, globus pallidus, and thalamus after striatal lesions as demonstrated by quantitative receptor autoradiography. J Neurosci 3:1189-1198.

Parent A, Csonka C, Etienne P. 1984. The occurrence of large acetylcholinesterase-containing neurons in human neostriatum as dis- closed in normal and Alzheimer-diseased brains. Brain Res 291: $154-158$.

Perry TL, Hansen S, Kloster M. 1973. Huntington's chorea. Deficiency of gamma-aminobutyric acid in brain. N Engl J Med 288:337-342.

Portera-Cailliau C, Hedreen JC, Price DL, Koliatsos VE. 1995. Evidence for apoptotic cell death in Huntington disease and excitotoxic animal models. J Neurosci 15:3775-3787.

Reynolds GP, Pearson SJ, Heathfield KW. 1990. Dementia in Huntington's disease is associated with neurochemical deficits in the caudate nucleus, not the cerebral cortex. Neurosci Lett 113:95-100.

Richfield EK, O'Brien CF, Eskin T, Shoulson I. 1991. Heterogeneous dopamine receptor changes in early and late Huntington's disease. Neurosci Lett 132:121-126.

Ruberg M, Mayo W, Brice A, Duyckaerts C, Hauw JJ, Simon H, LeMoal M, Agid Y. 1990. Choline acetyltransferase activity and $[3 \mathrm{H}]$ vesamicol binding in the temporal cortex of patients with $\mathrm{Alz}$ heimer's disease, Parkinson's disease, and rats with basal forebrain lesions. Neuroscience 35:327-333.

Smith PK, Krohn RI, Hermanson GT, Mallia AK, Gartner FH, Provenzano MD, Fujimoto EK, Goeke NM, Olson BJ, Klenk DC. 1985. Measurement of protein using bicinchoninic acid. Anal Biochem 150:76-85

Spokes EG. 1980. Neurochemical alterations in Huntington's chorea: a study of post-mortem brain tissue. Brain 103:179-210.

Turjanski N, Weeks R, Dolan R, Harding AE, Brooks DJ. 1995. Striatal D1 and D2 receptor binding in patients with Huntington's disease and other choreas. A PET study. Brain 118:689-696.

Vander Borght T, Kilbourn M, Desmond TJ, Kuhl D, Frey K. 1995a. The vesicular monoamine transporter is not regulated by dopaminergic drug treatments. Eur J Pharmacol 294:577-583.

Vander Borght TM, Sima AA, Kilbourn MR, Desmond TJ, Kuhl DE, Frey KA. 1995b. [3H] Methoxytetrabenazine: a high specific activity ligand for estimating monoaminergic neuronal integrity. Neuroscience 68:955-962.

Vonsattel JP, Myers RH, Stevens TJ, Ferrante RJ, Bird ED, Richardson EP Jr. 1985. Neuropathological classification of Huntington's disease. J Neuropathol Exp Neurol 44:559-577.

Walker FO, Young AB, Penney JB, Dovorini-Zis K, Shoulson I, 1984. Benzodiazepine and GABA receptors in early Huntington's disease. Neurology 34:1237-1240.

Weeks RA, Piccini P, Harding AE, Brooks DJ. 1996. Striatal D1 and D2 dopamine receptor loss in asymptomatic mutation carriers of Huntington's disease. Ann Neurol 40:49-54.

Whitehouse PJ, Lynch D, Kuhar MJ. 1984. Effects of postmortem delay and temperature on neurotransmitter receptor binding in a rat model of the human autopsy process. J Neurochem 43:553-559.

Whitehouse PJ, Trifiletti RR, Jones BE, Folstein S, Price DL, Snyder SH, Kuhar MJ. 1985. Neurotransmitter receptor alterations in Huntington's disease: autoradiographic and homogenate studies with special reference to benzodiazepine receptor complexes. Ann Neurol 18:202-210.

Wong PT, McGeer PL, Rossor M, McGeer EG. 1982. Ornithine aminotransferase in Huntington's disease. Brain Res 231:466-471. 